\title{
Amino Acid Composition and Proximate Analysis in Tilapia (Oreochromis Mossambicus) Fish from Dams and Rivers in Zamfara State, Nigeria
}

\author{
"MOSES, S; AGBAJI, EB; AJIBOLA, VO; GIMBA, CE
}

\author{
Department of Chemistry, Ahmadu Bello University, Zaria, Nigeria
}

*Corresponding Author Email: akamomoses@yahoo.com

\begin{abstract}
Twelve pieces of Tilapia mossambicus fish samples of $28 \mathrm{~cm}$ average length and $52 \mathrm{~g}$ average weight, two from each of the six sampling locations were analyzed for Amino Acid composition using Applied Biosystems PTH Amino Acid Analyzer as described by standard methods. A proximate analysis of the fish samples was also carried out. Result showed that Glutamic acid and Aspartic acid are the most concentrated amino acid present in the fish which ranged between 11.96 to $15.14 \mathrm{~g} / 100 \mathrm{~g}$ protein and 7.69 to $9.42 \mathrm{~g} / 100 \mathrm{~g}$ protein respectively. The essential amino acid and protein composition of the fish were higher in the dams than in the rivers. The composition of the amino acid analyzed were within standard regulatory agency limits. For the proximate composition, moisture content varied between $71.05 \%$ $77.71 \%$ while ash composition was $10.20 \%$. The crude fat composition ranged between $8.59-11.67 \%$ during the dry season. The values obtained for the proximate composition where within the reported ranges with higher percentage in the case of ash. The concentration of the proximate components in the fish samples are within the reference value of FAO/WHO for Humans. Special attention is needed in monitoring gold mining activities which largely contribute to the reduction and pollution of the nutritional qualities of the fishes from the rivers
\end{abstract}

\section{DOI: https://dx.doi.org/10.4314/jasem.v22i6.10}

Copyright: Copyright (C) 2018 Moses et al. This is an open access article distributed under the Creative Commons Attribution License (CCL), which permits unrestricted use, distribution, and reproduction in any medium, provided the original work is properly cited.

Dates: Received: 11 April 2018; Revised: 21 June: 2018; Accepted: 30 June 2018

Keyword: amino acid, proximate composition, tilapia fish, water bodies

Environmental pollution by toxic heavy metals does not only elicit concern in the metropolitan cities but also in remote and rural communities where anthropogenic activities, such as mining, are taking place. Gold mining and processing have been the main sources of heavy metal contamination in the environment (Duruibe et al., 2007; Boamponsem et al., 2010; Girigisu et al., 2012). The uncontrolled dissemination of waste effluents to large water bodies has negatively affected both water quality and aquatic life (Abdulrahman, et al., 2008). During the processing of the ores for gold, poisonous substances such as oxides and sulphides of heavy metal pollutants are released into the environment Boamponsem et al., (2010). Hence, most of the water sources particularly in Zamfara State are gradually becoming polluted due to the addition of these foreign materials from the environment. Contamination usually result from industrial activities, such as mining, electroplating, gas exhaust, energy and fuel production, fertilizer and pesticides application, and generation of municipal waste (Reports by Olaofe et al, 2004). Artisan mining is an important economic sector in many developing countries. However, limited resources and training, and the availability of cheap, but potentially hazardous methods of extraction and processing of minerals can cause significant threats to both miners and the local environment (Bitala, 2008; Armah et al., 2010). Such a scenario is being experienced in mining locations in Zamfara State. During peak mining periods, up to 5000 people invade the mining areas from outside the State. This has devastating effects on health and environment. Artisan mining in the areas conforms to neither mining laws nor regulations governing mining operations and environmental management. The miners are unaware of the effects of metal poisoning during mining and mineral processing. In principle, artisan gold mining in the areas is an informal sector with very little Government control. Haphazard mining in the mining areas has led to health effects ranging from respiratory problems to mental disorders. Studies in a similar region, in Tanzania revealed that symptoms of heavy metal poisoning such as sensory disturbance, hyporeflexia, tremor, gingivitis, metallic taste, neuroasthenia and night blindness are common (Harada et al., 1997; Akabzaa, 2000; Lottermoser, 2007). There have been several reports on acute lead $(\mathrm{Pb})$ poisoning outbreak among the dwellers of some remote villages of Zamfara State, Nigeria. This has been linked to the illegal mining operations by the people of remote communities (Galadima, 2012). Mercury as a pollutant in artisan mining, is due mainly 
to gold processing, when mercury is used to amalgamate gold. Cadmium, which is another common toxic metal, occupying position seven in the priority list of hazardous substances (ATSDR, 1999), generally occurs as an isometric trace element in sphalerite. Cadmium levels are likely to be quite low. Large amounts of $\mathrm{Hg}$ are released into the environment as a result of its usage in gold extraction. About $1.32 \mathrm{~kg}$ of $\mathrm{Hg}$ is lost for every $1 \mathrm{~kg}$ of gold produced which goes directly into water, soil and streams as inorganic $\mathrm{Hg}$ and later converted into organic forms (Matshusa et al., 2012). Several researchers have reported on its high concentration in gold mine tailings. Rafiei et al., (2010) reported 100 $\mathrm{mg} / \mathrm{kg}$ concentrations of $\mathrm{Hg}$ in Iran whereas Mathusa et al., (2012) reported concentrations as high as 1920 $\mathrm{mg} / \mathrm{kg}$ in Kenya. Some of the inorganic $\mathrm{Hg}$ that reaches aquatic ecosystems is converted by microbes into organic methylmercury $(\mathrm{MeHg})$, which accumulates in fish. Mercury compounds cause oxidative stress to bacterial cells due to imbalance between pro-oxidant and anti-oxidant homeostasis. They have high affinity for thiol group containing enzymes and proteins that serve as a line of cellular defense against $\mathrm{Hg}$ compounds. On gaining access to the cell, both $\mathrm{Hg}$ II $\left(\mathrm{Hg}^{2+}\right)$ and $\mathrm{MeHg}$ form covalent bonds with cysteine residues of proteins and deplete cellular antioxidants (Valko et al., 2006). The aim of this paper is to evaluate the amino acid composition and proximate analysis in Tilapia (Oreochromis mossambicus) fish from major dams and rivers in Zamfara State, Nigeria.

\section{MATERIALS AND METHODS}

In the preparation of solution, analytical reagent grade chemicals and distilled water were used. All glassware were washed with detergent and rinsed in water before immersion in $10 \%$ nitric acid solution. They were further rinsed with distilled water before drying in the oven (Ayodele et al., 1994).

Description of the Sampling Area: Zamfara State is located in the North Western Zone of Nigeria between Latitude $11^{\circ} 40^{\prime} \mathrm{E}$ and Longitudes $70^{\circ} 25^{\prime} \mathrm{E}$ with an altitude of $420 \mathrm{~m}$. The state inherited three major dams from the former Sokoto State in the quest to provide potable water for the teeming population. The dams are located in Gusau LGA (Gusau dam), Maradun LGA (Bakolori dam), and Maru LGA (Dangulubi dam). The dams are considered for investigation as a result of lead poisoning epidemic that struck the state sometimes around year 2010. The dams became very necessary to investigate because mining activities are still going on across the state in which water from the dams are used in the mining processes and more so because livestock are seen drinking from the dams and plants are sited growing around the vicinity of the mining areas. Three rivers were selected for investigation. The choice of the selected rivers in Anka was based on the report by MSF (Medecines Sans Frontiers) that villages such as Abare, Sunke and Bagega are contaminated with lead poisoning coming from extensive gold mining in those villages.

Collection of Fish Samples: Twelve pieces of Tilapia mossambicus fish samples of $28 \mathrm{~cm}$ average length and $52 \mathrm{~g}$ average weight, two from each of the six sampling locations was collected by a local fisherman. The fish samples were rinsed with distilled water immediately to remove any adhering contaminants and were stored in a frozen polythene bags. The fishes were immediately transported to a laboratory for proximate and amino acid analysis.

Determination of Crude Protein Content: The crude protein was determined by using microkjeldahl method as described by Pearson (1976). A known weight $(1.0 \mathrm{~g})$ of the fish sample weighed into a long necked Kjedahl flask along with $10 \mathrm{ml}$ of concentrated nitrogen free sulphuric acid. The flask was gently swirled and clamped in an inclined position and heated on a Bunsen burner. The heating continued strongly until a clear solution was obtained. The digestion lasted between 3 to 5 hours. The clear hot solution obtained was allowed to cool after which the solution was diluted with distilled water to $100 \mathrm{ml}$ in a standard flask. The distillation of the resulting solution was carried out. Then $25 \mathrm{ml}$ of $2 \%$ boric acid was pipette into a $100 \mathrm{ml}$ conical flask, 2 drops of mixed indicator (screened methyl red) was added and placed at receiving end of the distillation flask. The conical flask was placed in such a way that the delivery tube just touched the boric acid level inside the flask (Pearson, 1976). $40 \% \mathrm{NaOH}$ solution was used to liberated ammonia out of the digest during the distillation. The liberated ammonia was trapped in the boric acid solution. A blank sample was prepared as described above. The distillate was titrated with a standardized $0.10 \mathrm{~mol} / \mathrm{l} \mathrm{HCl}$ solution. Colour changed from blue to golden yellow. The bank solution was titrated as well.

$\%$ Nitrogen $=\frac{\text { Titre value } \times \text { M X } 0.0014}{\text { Wieght of sample }}$
$\%$ Crude protein $=\%$ Nitrogen $\times 6.25$.

Defatting Sample: The sample was defatted using chloroform/methanol mixture of ratio 2:1. About $4 \mathrm{~g}$ of the sample was put in extraction thimble and extracted for 15 hours in soxhlet extraction apparatus (AOAC, 2006). 
Nitrogen Determination: A small amount (200 mg) of ground sample was weighed, wrapped in whatman filter paper (No.1) and put in the Kjeldhal digestion flask. Concentrated sulphuric acid (10ml) was added. Catalyst mixture $(0.5 \mathrm{~g})$ containing sodium sulphate $\left(\mathrm{Na}_{2} \mathrm{SO}_{4}\right)$, copper sulphate $\left(\mathrm{CuSO}_{4}\right)$ and selenium oxide $\left(\mathrm{SeO}_{2}\right)$ in the ratio of 10:5:1 was added into the flask to facilitate digestion. Four pieces of antibumping granules were added. The flask was then put in Kjeldhal digestion apparatus for 3 hours until the liquid turned light green. The digested sample was cooled and diluted with distilled water to $100 \mathrm{ml}$ in standard volumetric flask. Aliquot $(10 \mathrm{ml})$ of the diluted solution with $10 \mathrm{ml}$ of $45 \%$ sodium hydroxide was put into the Markham distillation apparatus and distilled into $10 \mathrm{ml}$ of $2 \%$ boric acid containing 4 drops of bromocresol green/methyl red indicator until about $70 \mathrm{ml}$ of distillate was collected. The distillate was then titrated with standardize $0.01 \mathrm{~mol} / 1$ hydrochloric acid to grey coloured end point.

\section{Percentage Nitrogen $=\frac{(\mathrm{a}-\mathrm{b}) \times 0.01 \times 14 \times V \times 100}{\mathrm{~W} \text { X C }}$}

Where: $\mathrm{a}=$ Titre value $(\mathrm{ml})$ of the digested sample, $\mathrm{b}$ = Titre value of blank sample $\mathrm{V}=$ Volume after dilution $(100 \mathrm{ml}), \mathrm{W}=$ Weight of dried sample $(\mathrm{mg})$, $\mathrm{C}=$ Aliquot of the sample used $(10 \mathrm{ml}) \quad 14=$ Nitrogen constant in $\mathrm{mg}$.

Hydrolysis of the sample: A $30-35 \mathrm{mg}$ weighed of the defatted sample was introduced into glass ampoule. $7 \mathrm{ml}$ of $6 \mathrm{~mol} / \mathrm{l} \mathrm{HCl}$ was added and oxygen was expelled by passing nitrogen into the ampoule (this is to avoid possible oxidation of some amino acids during hydrolysis e.g. methionine and cystine). The glass ampoule was then sealed with Bunsen burner flame and put in an oven preset at $105^{\circ} \mathrm{C} \pm 5^{\circ} \mathrm{C}$ for 22 hours. The ampoule was allowed to cool before broken open at the tip and the content was filtered to remove the humins. It should be noted that tryptophan is destroyed by $6 \mathrm{~mol} / \mathrm{l} \mathrm{HCl}$ during hydrolysis. The filtrate was then evaporated to dryness in hot air oven. The residue was dissolved with $5 \mathrm{ml}$ to acetate buffer ( $\mathrm{pH}$ 2.0) and stored in plastic specimen bottles, which were kept in the freezer.

Loading of the Hydrolysates into the T.S.M. Analyzer: The amount loaded was 60 microlitre. This was dispended into the cartridge of the analyzer. The TSM analyzer is designed to separate and analyze free acidic, neutral and basic amino acids of the hydrolysate.

Statistical Analysis: Descriptive statistics (such as mean and standard deviation) were performed on all the data. A two way ANOVA was used to compare means of the different parameters measured for two seasons (wet and dry) and for two years (2014 and 2015). Duncan multiple range test was used to separate means where significant. Means were considered significantly different at $\mathrm{P}<0.05$. Correlation analysis was also conducted on the data at confidence level of 0.01 and 0.02 .

\section{RESULTS AND DISCUSSION}

Proximate Analysis (\%) of Fish Samples: The results of proximate analysis (\%) of fish samples collected from dams and rivers in Zamfara State for wet and two seasons of 2014 and 2015 respectively are presented in Tables 1a and b; $2 \mathrm{a}$ and b. A two way ANOVA analysis of variance $(\mathrm{P}>0.05)$ conducted on the fish showed that there is no significant difference from one location to another and on the seasons. Body composition is a good indicator for the physiological condition of fish. The percentage of water is a good indicator of its relative content of energy, proteins and lipids.

The lower the percentage of water, the greater the lipid and protein contents, and the higher the energy density of the fish (Dempson et al., 2004; Ali et al., 2005). The increased value of moisture content during the wet season may be due to increase rainfall which increase the volume of water on the body of the fish samples. This was also in close agreement with Davies and Davies (2009) who peg fish to be made up of $70-84 \%$ water.

The high moisture content of the fish sample would increase the deterioration level of the fish when kept for long time. This is because the micro-organisms would be highly active with high moisture content. The value of the ash content for both seasons were relatively similar except Bakolori dam during the dry season which recorded the lowest ash content, while Bagega river during the wet season recorded the highest ash content of $10.20 \%$. This result was also in agreement with Johnson, (2010) which reported that fresh water fish recorded the lowest ash and crude fibre content. The crude protein values for both seasons are relatively high, although those of Gusau dam to Dangulbi dam are higher than those of Bagega River to Abare River. This is an indication that the fish sample is a good source of protein. This is also an expected outcome since fish is a good source of protein (Tidwell, 2001). This very studies indicate that the crude protein content of the fish from Bagega river to Abare river are relatively lower when compared to that of the dams and other literatures. 
Table 1a: Proximate analysis (\%) of the Fish Samples from Dams in Zamfara State in both wet and dry seasons of 2014

\begin{tabular}{|c|c|c|c|c|c|c|}
\hline \multirow[b]{2}{*}{ C } & \multicolumn{2}{|l|}{ Gusau dam } & Bakolori & \multicolumn{3}{|c|}{ Dangulbi } \\
\hline & Wet & Dry & Wet & Dry & Wet & Dry \\
\hline Moisture & $76.48 \pm 3.03$ & $74.17 \pm 2.90$ & $75.69 \pm 2.36$ & $72.85 \pm 3.52$ & $77.71=1.08$ & $74.18=4.37$ \\
\hline $\begin{array}{l}\text { Ash } \\
\text { Protein }\end{array}$ & $\begin{array}{l}7.32=1.09 \\
65.49=3.30\end{array}$ & $\begin{array}{l}7.77 \pm 0.30 \\
65.84 \pm 3.98\end{array}$ & $\begin{array}{l}7.02=3.31 \\
63.35=4.41\end{array}$ & $\begin{array}{l}5.94 \pm 2.08 \\
63.48 \pm 10.73\end{array}$ & $\begin{array}{l}6.30=2.71 \\
61.74=5.95\end{array}$ & $\begin{array}{l}6.43 \pm 2.97 \\
60.41=7.25\end{array}$ \\
\hline Fat & $10.28=1.82$ & $10.74 \pm 2.86$ & $8.59=3.28$ & $10.53=6.48$ & $11.67=0.65$ & $13.53=4.21$ \\
\hline Fibre & $10.30=0.83$ & $10.15=1.56$ & $9.51=2.17$ & $8.95=3.70$ & $11.22=1.47$ & $10.44=2.55$ \\
\hline Carbohydrate & $6.61=4.04$ & $5.50=4.77$ & $8.79=2.42$ & $10.17=4.69$ & $9.39=3.52$ & $8.93=3.90$ \\
\hline Organic Matter & $92.68=1.10$ & $92.23=0.30$ & $92.98=3.31$ & $94.06 \pm 2.09$ & $93.70=2.71$ & $93.30=2.52$ \\
\hline
\end{tabular}

Table 1b: Proximate analysis (\%) of the Fish Samples from Rivers in Zamfara State in both wet and dry seasons of 2014

\begin{tabular}{lcccccc}
\hline & Bagega & \multicolumn{3}{c}{ Sunke } & \multicolumn{3}{c}{ Abare } \\
PC & Wet & Dry & Wet & Dry & Wet & Dry \\
\hline Moisture & $71.05 \pm 6.01$ & $69.85 \pm 4.60$ & $72.51 \pm 5.20$ & $68.07 \pm 2.83$ & $73.56 \pm 6.14$ & $72.89 \pm 6.69$ \\
Ash & $10.20 \pm 0.20$ & $8.76 \pm 1.39$ & $6.64 \pm 2.50$ & $6.77 \pm 2.68$ & $7.94 \pm 0.86$ & $7.35 \pm 0.99$ \\
Protein & $60.78 \pm 8.16$ & $59.51 \pm 3.45$ & $62.23 \pm 1.48$ & $62.01 \pm 7.79$ & $60.12 \pm 1.36$ & $61.09 \pm 3.47$ \\
Fat & $11.34 \pm 4.11$ & $10.90 \pm 2.73$ & $10.30 \pm 1.91$ & $12.31 \pm 5.35$ & $11.00 \pm 0.51$ & $10.95 \pm 0.79$ \\
Fibre & $10.18 \pm 2.29$ & $9.72 \pm 2.99$ & $10.64 \pm 1.45$ & $10.49 \pm 2.37$ & $9.31 \pm 0.31$ & $9.54 \pm 0.53$ \\
Carbohydrate & $7.48 \pm 3.12$ & $10.20 \pm 3.26$ & $10.51 \pm 2.08$ & $8.43 \pm 2.95$ & $11.29 \pm 2.28$ & $10.74 \pm 4.26$ \\
Organic Matter & $89.80 \pm 0.20$ & $91.25 \pm 1.40$ & $93.36 \pm 2.50$ & $93.23 \pm 2.68$ & $91.73 \pm 0.32$ & $92.32 \pm 0.73$ \\
\hline \multicolumn{7}{c}{$n=3 ;$ mean $\pm S . D$} \\
\end{tabular}

Table 2a: Proximate analysis (\%) of the Fish Samples from Dams in Zamfara State in both wet and dry seasons of 2015

\begin{tabular}{llcllll}
\hline & Gusau dam & \multicolumn{3}{c}{ Bakolori } & \multicolumn{2}{c}{ Dangulbi } \\
PC & Wet & \multicolumn{1}{c}{ Dry } & \multicolumn{1}{c}{ Wet } & \multicolumn{1}{c}{ Dry } & Wet & Dry \\
\hline Moisture & $76.45 \pm 3.03$ & $76.14 \pm 2.90$ & $74.67 \pm 2.36$ & $71.85 \pm 3.52$ & $77.11 \pm 1.08$ & $74.01 \pm 4.37$ \\
Ash & $6.32 \pm 1.09$ & $6.77 \pm 0.30$ & $6.06 \pm 3.31$ & $4.94 \pm 2.08$ & $6.33 \pm 2.71$ & $6.63 \pm 2.97$ \\
Protein & $65.48 \pm 3.30$ & $65.81 \pm 3.98$ & $63.35 \pm 4.41$ & $63.48 \pm 10.73$ & $61.70 \pm 5.95$ & $59.41 \pm 7.25$ \\
Fat & $11.28 \pm 1.82$ & $11.74 \pm 2.86$ & $8.59 \pm 3.28$ & $10.53 \pm 6.48$ & $11.60 \pm 0.65$ & $13.51 \pm 4.21$ \\
Fibre & $10.39 \pm 0.83$ & $10.19 \pm 1.56$ & $10.51 \pm 2.17$ & $9.95 \pm 3.70$ & $10.72 \pm 1.47$ & $10.21 \pm 2.55$ \\
Carbohydrate & $6.45 \pm 4.04$ & $5.40 \pm 4.77$ & $8.79 \pm 2.42$ & $10.17 \pm 4.69$ & $9.39 \pm 3.52$ & $8.93 \pm 3.90$ \\
Organic Matter & $93.68 \pm 1.10$ & $93.23 \pm 0.30$ & $93.98 \pm 3.31$ & $95.06 \pm 2.09$ & $93.64 \pm 2.71$ & $93.21 \pm 2.52$ \\
\hline \multicolumn{7}{c}{$\mathrm{n}=3 ;$ mean \pm S.D }
\end{tabular}

This may be due to activities done using the rivers which include but no limited to mineral exploitations, gold mining, farming and so on, which releases a lot of toxic metals into the river and may lead to eventual death of fish. Protein and fat are the major nutrient in fish and their level help to define the nutritional status of a particular organism (Aberoumad and Pourshafi, 2010). The chemical composition of fish varies from one individual to another depending on age, sex, environment and season with protein level ranging from 16 to $21 \%$, lipid from 0.1 to $25 \%$, ash 0.4 to $1.5 \%$, moisture content of 60 to $80 \%$ with extreme of $96 \%$ having been reported (Muchuweti et al., 2006). Of all the locations studied, Bagega River recorded the lowest glutamic acid level. This is immediately followed by Gusau Dam with glutamic acid value of $13.63 \mathrm{~g} / 100 \mathrm{~g}$ protein. This is consistent with the report of Adeyeye and Adamu (2005), Oshodi et al., (1993). Aspartic acid for all the locations ranged between 7.69 to $9.42 \mathrm{~g} / 100 \mathrm{~g}$ protein, again Bagega River here recorded the lowest value. Glutamic acid and aspartic acids were the most concentrated amino acids in the fish samples, both of which are acidic amino acids. Olaofe and his co-workers (1993, 1994), Oshodi et al., (1993) and Adeyeye and Adamu (2005) reported similar values in glutamic acid and aspartic acids. Aspartic acid is interconvertible with asparagine, and therefore the two amino acids have many functions in common. It increases stamina. One of the two main excitatory amino acids, the other being glutamate (glutamic acid) helps in protecting the liver by aiding the removal of ammonia. Cystine (Cys) is the least amino in all the six (6) locations studied for amino acid, with a value that ranged between $0.73-0.85$ $\mathrm{g} / 100 \mathrm{~g}$ protein. Cysteine and Cystine are interconvertible. Two molecules of Cysteine make cystine. It acts as an Antioxidant. Protective against radiation, pollution, ultra-violet light and other causes of increased free radical production. It is essential in growth, maintenance, and repair of skin. Its deficiency is seen in chemical sensitivity and food allergy (Ali et al., 2005). The lysine content of the fish sample (5.62 $-7.85 \mathrm{~g} / 100 \mathrm{~g}$ crude protein) was closed to the content of the reference egg protein $(63 \mathrm{mg} / \mathrm{g})$, which will therefore serve as a good source for fortification of cereal weaning foods. It also helps to form collagen, the connective tissue present in bones, ligament, tendons, and joints. It assists in the absorption of calcium. It is also essential for children, as it is critical for bone formation (Ali et al., 2005). 
Table 2b: Proximate analysis (\%) of the Fish Samples from Rivers in Zamfara State in both wet and dry seasons of 2015

\begin{tabular}{lllllll}
\hline & Bagega & \multicolumn{3}{c}{ Sunke } & \multicolumn{3}{c}{ Abare } \\
PC & Wet & \multicolumn{1}{c}{ Dry } & Wet & Dry & Wet & Dry \\
\hline Moisture & $71.05 \pm 6.01$ & $69.85 \pm 4.60$ & $72.51 \pm 5.20$ & $68.07 \pm 2.83$ & $71.56 \pm 6.14$ & $70.89 \pm 6.69$ \\
Ash & $11.21 \pm 0.20$ & $9.74 \pm 1.39$ & $6.64 \pm 2.50$ & $6.77 \pm 2.68$ & $7.94 \pm 0.86$ & $7.35 \pm 0.99$ \\
Protein & $60.78 \pm 8.16$ & $59.51 \pm 3.45$ & $62.23 \pm 1.48$ & $62.01 \pm 7.79$ & $62.12 \pm 1.36$ & $63.09 \pm 3.47$ \\
Fat & $11.34 \pm 4.11$ & $10.90 \pm 2.73$ & $10.30 \pm 1.91$ & $12.31 \pm 5.35$ & $11.00 \pm 0.51$ & $10.95 \pm 0.79$ \\
Fibre & $10.18 \pm 2.29$ & $9.72 \pm 2.99$ & $10.94 \pm 1.45$ & $10.78 \pm 2.37$ & $9.31 \pm 0.31$ & $9.54 \pm 0.53$ \\
Carbohydrate & $7.48 \pm 3.12$ & $10.20 \pm 3.26$ & $10.21 \pm 2.08$ & $8.43 \pm 2.95$ & $11.20 \pm 2.28$ & $10.20 \pm 4.26$ \\
Organic Matter & $88.81 \pm 0.20$ & $90.22 \pm 1.40$ & $93.36 \pm 2.50$ & $91.87 \pm 2.68$ & $91.73 \pm 0.32$ & $92.32 \pm 0.73$ \\
\hline \multicolumn{7}{c}{$\mathrm{n}=3$; mean \pm S.D }
\end{tabular}

Arginine is an essential amino acid for children growth (Robinson, 1987) and it is relatively high in the fish samples, this is in agreement with the result of Adeyeye (2005). The total essential amino acids in the fish sample ranged between 33.95 - 42.58g/100g crude protein without tryptophan (which was not determined) which is between $67-76.5 \%$ egg reference proteins $(566 \mathrm{mg} / \mathrm{g}$ ) (Paul et al., 1980).This suggests that the fish sample would contribute significantly to the supply of essential amino acid in the diet. The result on total essential amino acid is comparable to some literature reports of $351 \mathrm{mg} / \mathrm{g}$ in Zonocerus variegatus (Adeyeye, 2005a), 350.3mg/g in Macrotermes bellicosus (Adeyeye, 2005b), 480mg/g in Limicolonia spp, $361 \mathrm{mg} / \mathrm{g}$ in Archattina archattina and $450 \mathrm{mg} / \mathrm{g}$ in Archattia marginata (Adeyeye and Afolabi, 2004) and 354mg/g in Gymnarchus niloticus (Adeyeye and Adamu, 2005). The total Sulphur amino acid (TSAA) ranged between $2.60-3.09 \mathrm{~g} / 100 \mathrm{~g}$ crude protein which was below the recommended value of $58 \mathrm{mg} / \mathrm{g}$ for infant (FAO/WHO/UNU, 1985).

Table 3: Amino acid composition of fish from major dams and rivers FAO/WHO/1985

\begin{tabular}{|c|c|c|c|c|c|c|c|c|}
\hline Amino acid & Ll & L2 & L3 & L4 & L5 & L 6 & $\begin{array}{l}\text { Children } \\
\text { renuirement }\end{array}$ & $\begin{array}{l}\text { Ad ult } \\
\text { ren nirement }\end{array}$ \\
\hline Leusine (Leul) & $7.00 \pm 0.02$ & $7.18 \pm 0.04$ & $0.03 \pm 0.05$ & $2.00=0.04$ & $0 . / / \pm 0.05$ & $0.15 \pm 0.05$ & 0.00 & 5.90 \\
\hline Lysine (Lys) & $7.50 \pm 0.01$ & $7.85 \pm 0.03$ & $7.69=0.05$ & $5.62 \pm 0.02$ & $6.84 \pm 0.02$ & $6.31=0.05$ & 4.80 & 4.50 \\
\hline Isole ucine(Tle)e & $3.60 \pm 0.01$ & $3.86 \pm 0.04$ & $3.40=0.04$ & $3.21 \pm 0.02$ & $3.51=0.01$ & $3.40 \pm 0.02$ & 3.00 & 3.00 \\
\hline Phenylabine (Phy)e & $4.20=0.02$ & $3.90=0.02$ & $3.55 \pm 0.01$ & $3.28=0.02$ & $3.72=0.04$ & $3.55 \pm 0.05$ & 4.10 & 3.80 \\
\hline Valine (Val)e & $3.92 \pm 0.04$ & $4.44 \pm 0.02$ & $3.39 \pm 0.03$ & $3.33 \pm 0.01$ & $3.80 \pm 0.04$ & $3.62 \pm 0.04$ & 2.90 & 3.90 \\
\hline Methionine (Met) & $2.24 \pm 0.02$ & $2.19 \pm 0.5$ & $2.08 \pm 0.04$ & $1.87 \pm 0.03$ & $2.19 \pm 0.05$ & $1.98=0.04$ & 2.30 & 1.60 \\
\hline Proline (Pro) & $4.47 \pm 0.03$ & $4.06 \pm 0.2$ & $3.86 \pm 0.02$ & $3.45 \pm 0.01$ & $4.26 \pm 0.04$ & $3.96 \pm 0.02$ & & \\
\hline $\begin{array}{l}\text { Arginine (Arg) } \\
\text { Tyrosine (Tyr) }\end{array}$ & $\begin{array}{l}5.85=0.03 \\
2.92 \pm 0.02\end{array}$ & $\begin{array}{l}6.19 \pm 0.03 \\
3.10 \pm 0.02\end{array}$ & $\begin{array}{l}5.16 \pm 0.02 \\
2.24 \pm 0.02\end{array}$ & $\begin{array}{l}5.33 \pm 0.03 \\
2.41 \pm 0.01\end{array}$ & $\begin{array}{l}5.94 \pm 0.02 \\
2.92 \pm 0.04\end{array}$ & $\begin{array}{l}5.85 \pm 0.01 \\
2.92 \pm 0.02\end{array}$ & & \\
\hline Histidine $(\mathrm{His})^{\text {be }}$ & $2.81=0.01$ & $2.75 \pm 0.01$ & $2.24 \pm 0.02$ & $2.49=0.05$ & $3.00 \pm 0.04$ & $2.87 \pm 0.05$ & 1.60 & 1.50 \\
\hline Cytine(Cys) & $0.85 \pm 0.03$ & $0.85 \pm 0.01$ & $0.73 \pm 0.01$ & $0.73 \pm 0.01$ & $0.85 \pm 0.05$ & $0.73 \pm 0.03$ & & \\
\hline Alanine (Ala) & $5.84 \pm 0.02$ & $5.69 \pm 0.03$ & $5.23 \pm 0.01$ & $4.32 \pm 0.02$ & $5.12 \pm 0.04$ & $4.93 \pm 0.05$ & & \\
\hline Glut amic Acid (Glu) ${ }^{2}$ & $13.63 \pm 0.3$ & $14.23 \pm 0.03$ & $14.84 \pm 0.0$ & $11.96 \pm 0.02$ & $15.14 \pm 0.02$ & $14.69 \pm 0.03$ & & \\
\hline Gycine (Gly) & $6.56 \pm 0.04$ & $6.17 \pm 0.05$ & $5.23 \pm 0.04$ & $5.08 \pm 0.04$ & $5.75 \pm 0.03$ & $5.51 \pm 0.05$ & & \\
\hline Thre onine(Thr) ${ }^{e}$ & $3.72 \pm 0.04$ & $4.22 \pm 0.02$ & $3.22 \pm 0.04$ & $3.22 \pm 0.02$ & $3.91=0.05$ & $3.66 \pm 0.02$ & 2.50 & 2.30 \\
\hline Serine(Ser) & $4.00 \pm 0.02$ & $3.67 \pm 0.03$ & $3.13 \pm 0.03$ & $2.97 \pm 0.03$ & $3.51=0.03$ & $3.25 \pm 0.01$ & & \\
\hline Aspartic Acid $(A \unlhd p)^{2}$ & $8.81 \pm 0.03$ & $9.42 \pm 0.02$ & $8.12 \neq 0.02$ & $7.69=0.01$ & $9.18 \pm 0.02$ & $8.70=0.04$ & & \\
\hline
\end{tabular}

The data are means and standard deviations of duplicate values. Key: $a=$ amino acid, $\boldsymbol{b}=b a \operatorname{sic}$ and $\boldsymbol{e}=\mathbf{e s s e n t i a l}$

Table 4: Essential, Non-Essential, Acidic, Basic, Neutral, Aromatic Amino Acid (g/100g) Protein of Fish Sample (Dry Weight)

\begin{tabular}{lllllll}
\hline Amino Acids & L1 & L2 & L3 & L4 & L5 & L6 \\
\hline Total Amino Acid(TAA) & 88.01 & 89.77 & 86.41 & 82.26 & 80.76 & 72.56 \\
Total non-essential Amino & 47.08 & 47.19 & 46.73 & 44.89 & 46.6 & 38.61 \\
Acid(TNEAA) & & & & & & \\
Total essential amino acid(TEAA) & & & & & & \\
With HIS & 40.93 & 42.58 & 39.68 & 37.37 & 34.16 & 33.95 \\
No HIS & 38.12 & 39.83 & 36.68 & 34.5 & 31.92 & 31.46 \\
\% TNEAA & 53.49 & 52.57 & 54.08 & 54.57 & 57.7 & 53.21 \\
With HIS & 46.51 & 47.43 & 45.92 & 45.43 & 42.3 & 46.79 \\
No HIS & 43.31 & 44.37 & 42.45 & 41.94 & 39.52 & 43.36 \\
Total neutral Amino Acid(TNAA) & 49.38 & 49.33 & 46.31 & 43.64 & 42.71 & 39.47 \\
Total Acidic Amino Acid(TAAA) & 22.44 & 23.65 & 24.32 & 23.56 & 22.96 & 19.65 \\
\% TAAA & 25.5 & 26.35 & 28.14 & 28.64 & 28.43 & 27.08 \\
Total Basic Amino Acid(TAAA) & 16.19 & 16.79 & 15.78 & 15.03 & 15.09 & 13.44 \\
\% TBAA & 18.4 & 18.7 & 18.26 & 18.27 & 18.68 & 18.52 \\
\hline
\end{tabular}




\begin{tabular}{|c|c|c|c|c|c|c|c|}
\hline Amino Acids & $\begin{array}{l}\text { Provisional Amino Acid } \\
\text { Scoring Pattern(a) }\end{array}$ & L1 & L2 & $\mathbf{L 3}$ & L4 & L5 & L6 \\
\hline Isoleucine & 40.00 & 0.900 & 0.965 & 0.850 & 0.803 & 0.878 & 0.850 \\
\hline Leucine & 70.00 & 1.000 & 1.030 & 0.950 & 0.800 & 0.977 & 0.901 \\
\hline Lysine & 55.00 & 1.360 & 1.430 & 1.400 & 1.020 & 1.240 & 1.150 \\
\hline Met+cys(TSAA) $)^{b}$ & 35.00 & 0.880 & 0.870 & 0.800 & 0.740 & 0.870 & 0.770 \\
\hline Phe+tyr(TArAA) ${ }^{c}$ & 60.00 & 1.200 & 1.170 & 0.970 & 0.950 & 1.110 & 1.080 \\
\hline Threonine & 40.00 & 0.930 & 1.060 & 0.810 & 0.810 & 0.980 & 0.920 \\
\hline Tryptophan & 10.00 & nd & nd & nd & nd & nd & nd \\
\hline Valine & 50.00 & 0.780 & 0.890 & 0.680 & 0.670 & 0.760 & 0.720 \\
\hline
\end{tabular}

This may be one of the causes of illnesses as a result of malnutrition in children reported by MSF (2010), and that with the outbreak of lead poisoning incidence in Zamfara State, at least 10,000 people of which 2000 children under the age of 5years are in danger of death or severe illness from seven villages. The total aromatic amino acid (ArAA) of the fish sample from all the six (6) locations ranged between 5.74 $7.12 \mathrm{~g} / 100 \mathrm{~g}$ crude protein which is in close range with values suggested for ideal infant protein 68 to $188 \mathrm{mg} / \mathrm{g}$ crude protein (FAO/WHO/UNU, 1985). Protein is made up of acidic, basic and neutral amino acids, this present investigation revealed that neutral amino acid is the most abundant in the fish sample from all the locations under study. While total basic amino acid is the least abundant. The entire fish sample protein is likely to be acidic, this is because the percentage total acidic amino acid ranged between $25.50-28.64 \%$ is greater than the percentage total basic amino acid which ranged between 18.26 $18.70 \%$. The amino acid scores further suggest that valine an essential amino acid has the lowest amino acid score with value between $0.67-0.89$ (67- 89\%). Valine one of the 3 major branched chain amino acids (BCAA) the other 2 being leucine and isoleucine of which are involved in muscle strength, endurance and muscle stamina. Any acute physical stress (including surgery sepsis, fever, trauma, starvation) requires higher amounts of valine, leucine and isoleucine than any other amino acids.

Conclusion: The analysis of the amino acid of the fish sample, mining of gold has had influence on the nutritional quality and quantity of the fish. This is especially so because of the low concentrations of the essential amino acid concentration of the fish from the rivers which are predominantly area of gold miners. The amino acid profile of the fish sample revealed that Glutamic acid and Aspartic acid are the most concentrated amino acid present in the fish, while the Lysine content of the fish can serve as a good source of protein for the fortification of cereal weaning foods.
Acknowledgement: am particularly grateful to my team of supervisors, whose immense contributions have made this work a success and my parent for their financial support.

\section{REFERENCE:}

Abdulrahman, MO; Reshma D'Souza, (2008). The effects of different methods of cooking on proximate, mineral and heavy metal composition of fish and shrimps consumed in the Arabian Gulf. Archivos Latinomericanos De Nutricion Organo Official de la Sociedad Latinoamericana de Nutricion 58 (1) 103-109

Aberoumad, A; Pourshafi, K (2010). Chemical and proximate composition properties of different fish species obtained from Iran. World J. Fish Mar. Sci. 2 (3): 237-239.

Adeyeye, EI; Adamu AS (2005). Chemical Composition and food properties of Gymnarchus Niloticus (Trunk fish). Bioscience, Biotechnology Research Asia. 3 (2) 265 272.

Agency for Toxic Substances and Disease Registry (ATSDR) 1999. Lead. US Public Health Service.

Akabzaa, TM (2000). Boom and Dislocation: A Study of the Social and Environmental Impacts of Mining in the Wassa West District of Ghana. Third World Network, Africa Secretariat; Accra, Ghana. 2(5): 124-212.

Ali, M; Iqbal, F; Salam, A; Iram, S; Athar, M (2005). Comparative study of body composition of different fish species from brackish water pond. Inter. J. Environ. Sci. Technol. 2(3): 229-232

Armah, FA; Obiri, S; Yawson, DO; Pappoe, ANM; Bismark, A (2010). "Evaluation of Heavy Metals in Fishes, Water and Sediments of Lake Kainji, Nigeria," $J$. Environ. Stat. 1:212-218.

Association of Official Analytical Chemists (AOAC) (2006). Official Method of analysis (15 ${ }^{\text {th }}$ ed.) Washington D.C.

Ayodele, JT; Gaya, UM (1994). Determination of Lead in Street Dust to Index its Pollution in Kano Municipal. Spectrum Journal, I: 94-97. 
Bitala, MF (2008). Environmental Chemstry of the elements. Academic Press Inc. London. pp: 1329.University of Dares Salaam. Pp 1-61.

Boamponsem, LK; Adam, JI; Dampare, SB; Owusu-Ansah, E; Addae, G (2010). Studies on the histopatholoigcal changes in selected tissues of fish Labeo rohita to phenol. J. Chem. Pharm. Res 2: 504-527.

Davies, OA; Allison, ME; Uyi, HS (2009). Bioaccumulation of heavy metals in water, sediment and periwinkle (Tympanotonus fuscatus var radula) from the Elechi Creek, Niger Delta. Afr. J. Biotechnol. 5 (10): 968-973.

Dempson, IB; Schwarz, CJ; Shears, M; Furey, G (2004). Comparative proximate body composition of Atlantic salmon with emphasis on parr from fluvial and lacustrine habitats. J. Fish Biol. 64: 1257-1271

Duruibe, TO; Ogwuegbu, MOC; Egwurugwu, JN (2007). Practical Information on Surface Water Problems. Int $J$ Phys Sci 2: 112-118.

FAO/WHO/UNU (1985). Energy and Protein requirements. Report of a joint FAO/WHO/UNU. Expert Consultation on Energy and protein requirements. World Health Organization Technical Report series 724, WHO. Geneva. Switzerland pp. 113-129

Galadima, A (2012). Arsenic level speciation in fresh water from Karaye Local Government Area, Kano State, Nigeria.Available online at www.saharareporters.org (Accessed on September 2013).

Girigisu, S; Ibeanu, IGE; Adeyemo, DJ; Okoh, S (2012). Methods for Physical and Chemical Analysis of Fresh Waters. American J. Appl. Sci. 9: 1014-1019. No paper title

Harada, M (1997). Neurotoxicity of Methyl-mercury: Minamata and the Amazon, in: M. Yasui, M.J. Strong, K.

Ota and M.A. Verity (eds), Mineral and Metal Neurotoxicology, CRC Press, Tokyo, pp. 177-188.

Johnson, AR; Munoz, A; Gottlieb, JL; Jarrard, DF (2007). High dose zinc increases hospital admissions due to genitourinary complications. J. Urol. 177 -.639-643.

Lottermoser, B (2007). Mine Wastes: Characterization, Treatment and Environmental Impacts. Springer; New York, NY, USA: pp. 1-290.

Matshusa, K; Ogola, JS; Maas, K (2012). Dispersion of metals at Louis Moore gold tailings dam, Limpopo province, South Africa; Proceedings of the
International Mine Water Association Symposium; Bunbury, Australia; pp. 334A-334E.

Muchuweti, MJ; Birkett, JW; Chinyanga, E; Zvauya, R; Scrimshaw, MD; Lester;

Muraleedharan, V; Antony, KP; Perigreen, PA; Gopakumar, $\mathrm{K}$ (2006). Utilization of unconventional fish resources for surimi preparation. Proceedings of the second workshop on scientific results of FORV SAGAR. Sampada. Dept. of Ocean development. New Delhi, (India). pp. 539-543

Olaofe, O; Arogundade, LA; Adeyeye, ET; Falusi, OM (1998). Composition and Food Properties of the variegated grasshopper, Zonocerus Variegagtes Trop. Sci., 38, 233-237.

Olaofe, O; Faleye, FJ; Adebiyi, AS (2004): Amino Acid Composition of Variegated grasshopper, (Zenocers Variegatus), L. and Infra-Red Characterization of Its Oils. Inter. J. Chem.

Oshodi, AA; Olaofe, O; Hall, GM (1993). Amino Acid, Fatty acid and mineral composition of Pigeon Pea (Cajanus Cajan). Inter. J. Food Sci. Nutri. 43, 187-191.

Paul, AA; Southgate, DAT; Russels, H (1980). First supplement to McCance and Widdowson's. The composition of foods, HMSO, London and Elsevier, New York.

Pearson, D (1976). Chemical analysis of Food. $7^{\text {th }}$ Edition. J. and A. Churchil London U.K pp 7-11.

Rafiei, B; Bakhtiari Nejad, M; Hashemi, M; Khodaei, A (2010). Distribution of heavy metals around the Dashkasan Au mine. Int. J. Environ. Res.; 4:647-654.

Robinson, OS (1987). Food Biochemistry and Nutritional value. Longman Scientific and Technical, UK pp. 137149.

Tidwell, JH; Alla, GL (2001). Fish as food: aquaculture's contribution Ecological and economic impacts and contributions of fish farming and capture fisheries. Sci. Soc. 2(11): 958-63.

Valko, M; Rhodes, C; Moncol, J; Izakovic, M; Mazur, M (2006). Free radicals, metals and antioxidants in oxidative stress-induced cancer. Chem. Biol. Interact; 160:1-40.

WHO 2009. Joint WHO/Convention Task Force on the Health Aspects of Air Pollution, Health risks of heavy metals from long-range trans-boundary air pollution, 2009, World Health Organization, Geneva. 